\title{
Carbon export and sequestration in the southern Benguela upwelling system: lower and upper estimates
}

\author{
H. N. Waldron ${ }^{1}$, P. M. S. Monteiro ${ }^{1,2}$, and N. C. Swart ${ }^{1, *}$ \\ ${ }^{1}$ Department of Oceanography, University of Cape Town, Rondebosch 7700, South Africa \\ ${ }^{2}$ Ocean Systems \& Climate Group, CSIR, P.O. Box 320, Stellenbosch 7599, South Africa \\ *now at: Earth and Ocean Science, University of British Columbia, 6339 Stores Road, Vancouver, V6T 1Z4, Canada
}

Received: 15 May 2009 - Published in Ocean Sci. Discuss.: 25 June 2009

Revised: 9 December 2009 - Accepted: 10 December 2009 - Published: 18 December 2009

\begin{abstract}
Three independent studies of carbon export and sequestration in the southern Benguela upwelling system are presented. They were undertaken by Waldron (upwelling index), Monteiro (discrete upwelling centres - gate hypothesis model) and Swart (cross-shelf advection in bottom nelpheloid layers). The annual estimates were, $3.9 \times 10^{13}$, $0.72 \times 10^{13}$ and $8.6 \times 10^{11} \mathrm{gC}$, respectively. The lowest estimate was derived from a consideration of low frequency lateral carbon export in the bottom nepheloid layer and was thought likely to be an under-estimate. Taking into account high frequency episodic events, intermediate nepheloid layers and along isopycnal export of DOC at surface and intermediate depths was thought likely to result in a substantial upward revision. The remaining two estimates were considered to be an upper and lower estimate of carbon export and sequestration due to factors inherent in the methodologies. The upper estimate presents a two-dimensional system, integrated alongshore; the lower estimate sums a series of upwelling centres in order to obtain a system flux. The former is therefore a uniform extrapolation along the coast while the latter omits upwelling between the upwelling centres.
\end{abstract}

\section{Introduction}

The continental margins account for $7 \%$ of the world ocean surface area. They are however, subject to seasonal or subseasonal inputs of nutrients accompanied by high rates of primary production and biomass. The former (seasonal) occurs in shelf seas and the latter (sub-seasonal) in upwelling sys-

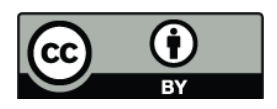

Correspondence to: H. N. Waldron

(howard.waldron@uct.ac.za) tems. Eastern boundary upwelling systems cover $1 \%$ of the ocean surface area but are estimated to account for $11 \%$ of new production fluxes (Chavez and Toggweiler, 1995; Monteiro, 2009). Significant primary productivity and new production fluxes in coastal systems translate into a relatively high proportion of the $\mathrm{CO}_{2}$ uptake by the coastal oceans $\left(0.36 \mathrm{GtCy}^{-1}\right.$ cf global sink of $1.8 \pm 0.7 \mathrm{GtCy}^{-1} \sim 15 \%$ (Doney et al., 2009; Chen and Borges, 2009).

Previous studies have supported the view that the modest areal extent of the ocean margins account for a disproportionately large fraction of total ocean productivity (Walsh et al., 1981; Wollast, 1998; Chen et al., 2003; Rullktter, 2000; Falkowski et al., 2003). Since the early 1980s there has been a combination of conjecture, experimental research and rejected hypotheses relating to the continental margin's role in the export of carbon. In respect of the north east USA, estimates of carbon export from shelf to slope have varied from $50 \%$ of unconsumed biological material (Walsh et al., 1981; Malone et al., 1983), later revised to $<20 \%$ of primary production (Rowe et al., 1986) and subsequently $<5 \%$ (Biscaye et al., 1994). These studies neglected to consider the substantial pool of dissolved organic carbon (DOC). Hopkinson Jr. et al. (2002) asserted that the DOC pool represented the most significant organic carbon reservoir in the ocean and that shelf export of DOC could be large. Chen et al. (2003) distinguished between re-cycling and export margins on the basis of shelf topography and residence time versus major coastal upwelling. Their paper further stated that continental shelves are net sinks for atmospheric $\mathrm{CO}_{2}$, and that where export occurs, it is dominated by fluxes in the DOC pool. Recent reassessments of coastal systems as $\mathrm{CO}_{2}$ sinks have helped to resolve the controversy on the magnitude of the coastal $\mathrm{CO}_{2}$ sink by assigning a reduced role to terrestrial POC fluxes in coastal remineralization (Chen and Borges, 2009). The

Published by Copernicus Publications on behalf of the European Geosciences Union. 
conclusions were that coastal systems are net sinks of atmospheric $\mathrm{CO}_{2}\left(\sim 0.36 \mathrm{GtCy}^{-1}\right)$ because a much larger fraction of terrestrial POC is trapped by estuarine systems (Chen and Borges, 2009). The southern Benguela upwelling system is a good system to explore this question because the terrestrial POC and nutrient input to the shelf system is insignificant and the $\mathrm{CO}_{2}$ sink will therefore depend mostly on ocean - shelf exchange of the different carbon fractions (Monteiro, 2009; Santana-Casiano et al., 2009). The role of shelf bathymetry and dynamics has been recognised as being important to the export of remineralised $\mathrm{TCO}_{2}$ (Ianson et al., 2009). Here we expand this to show the link between the magnitude of the $\mathrm{CO}_{2}$ sink and the export of POC and DOC. We hypothesize that this atmospheric $\mathrm{CO}_{2}$ sink is linked to the magnitude of the carbon export across the ocean-shelf boundary (Waldron et al., 1997; Monteiro, 2009).

Three different methods of quantifying carbon [POC \& DOC] export in the southern Benguela upwelling system are examined here. The first adopts an approach that is regional in space and annual in time using an upwelling index and fluxes of nitrate (converted to carbon), the second compartmentalizes the upwelling space scale into those of discrete centres and takes into account transports of dissolved inorganic carbon (DIC), and particulate and dissolved organic carbon (POC and DOC). The third models cross-shelf advection of $\mathrm{POC}$ in the bottom nepheloid layer and recognizes the importance of DOC flux. It is our contention that the estimates of carbon export presented here represent lower and upper boundaries.

\section{Methods and results}

The detail of the methods for the three different approaches have been fully described in Waldron et al. (1997), Waldron et al. (1998), Monteiro (1996) and Swart (2008) but the essence of each is described briefly below.

\subsection{Waldron: upwelling index}

A two-dimensional network of $\mathrm{NO}_{3}-\mathrm{N}$ (and subsequently carbon) pathways between open ocean, shelf and sediments is shown in Fig. 1.

- "A" is upwelling source water nitrate (South Atlantic Central Water).

- "B" is shelf re-cycled nitrate.

- "C" represents the southern Benguela annual potential production due to nitrate. It consists of the nitrate-based production due to the sum of source "A" (referred to as $C(a)$ ) and source "B" (referred to as C(b)). C(a) is the annual potential new production (APNP) since the nitrate sustaining this production is "new" to the system. $\mathrm{C}(\mathrm{b})$ is sustained by a shelf-recycling loop of nitrate and cannot be considered as new production per se. This

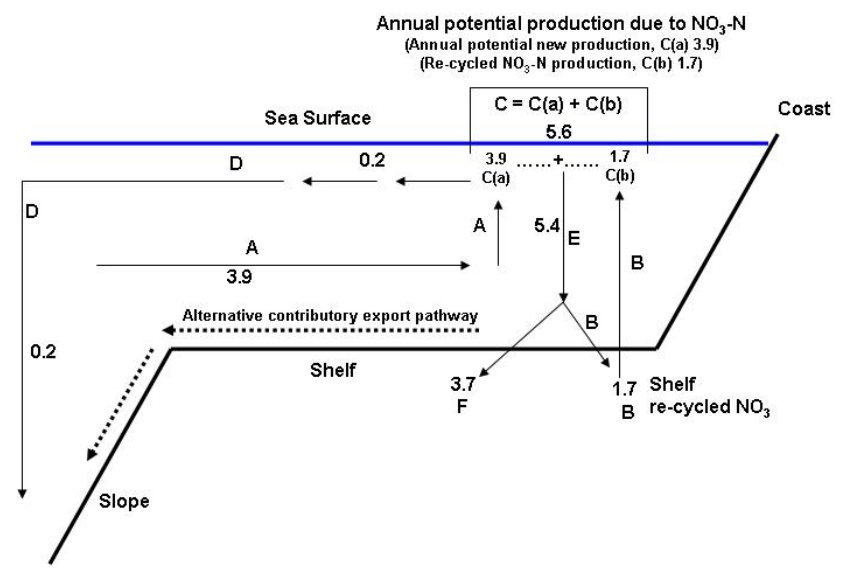

Fig. 1. Two-dimensional network of $\mathrm{NO}_{3}-\mathrm{N}$ driven carbon pathways in the southern Benguela upwelling system.

follows Roemmich (1989) who applied the same distinction referring to "imported new" production $(\mathrm{C}(\mathrm{a})$ in this study) and "local new" production $(\mathrm{C}(\mathrm{b})$ in this study).

- "D" is the proportion of APNP that is advected offshore (in surface waters) and, ultimately, sequestrated below the permanent thermocline.

- "E" is the proportion of annual potential nitrate production (C) that sinks over the shelf.

- "F" is the proportion of "E" that is sequestrated in shelf sediments. NB the remaining proportion of "E" reenters the shelf re-cycling pathway ("B").

Budgetary considerations at the annual scale indicate simple algebraic linkages between these variables:

"C" = "A"+ "B"

"C" = "D"+ "E"

$" E "=" F "+" B "$

If estimates can be given for, say pathways " $C$ ", " $B$ " and " $D$ " then pathways "A", "E" and "F" can be solved by algebraic substitution. "C" - southern Benguela Annual Potential Production due to nitrate

Over a period of a year, upwelling occurs as a series of events. Event-scale upwelling can be identified from satellite images of sea surface temperature (SST). A relationship was established between SST and nitrate integrated over a nominal euphotic zone $(30 \mathrm{~m})$. Therefore from satellite image records of SST it was possible to identify upwelling events of varying intensity and estimate the quantity of nitrate per event that was available to the euphotic zone. These upwelling events (and their associated nitrate content) were positively related to the coastal sea level fluctuation evident 
in the tide gauge record resulting from coastal trapped wave activity. Upwelling events and coastal trapped waves are meteorologically-forced. The event-scale sea level fluctuations caused by the propagation of coastal trapped waves (tide gauge data filtered of tide and atmospheric pressure) were related to coincident upwelling events and their nitrate content and were hence used as an upwelling proxy to estimate annual fluxes of nitrate.

“C” $=5.6(3.9-7.3) \times 10^{13}$ gCyear $^{-1}$

(numbers in parentheses refer to the range in the 1980s dataset).

"B" - Shelf re-cycled nitrate.

South Atlantic Central Water (SACW) has a median nitrate signature of $14 \mathrm{mmol} \mathrm{m}^{-3}\left(10-18 \mathrm{mmol} \mathrm{m}^{-3}\right)$ and water which actually upwells after nitrate enhancement has a mean nitrate signature of $20( \pm 4) \mathrm{mmol} \mathrm{m}^{-3}$. The enhancement results from interaction between $\mathrm{SACW}$ and nutrientrich shelf waters (which have been subject to $\mathrm{NO}_{3}-\mathrm{N}$ inputs due to shelf re-mineralisation). Assuming that the nitrate concentration difference between SACW and water which upwells remains more or less fixed within their respective ranges, $30 \%$ of " $\mathrm{C}$ " can be considered locally re-cycled production due to nitrate: (20-14)/20 expressed as a percentage.

"B" $=1.7(1.2-2.2) \times 10^{13} \mathrm{gCyear}^{-1}$

"D" - Annual potential production due to nitrate advected offshore.

Pathway "D" accounts for the amount of potential production due to nitrate that is advected offshore and was obtained from integrated nitrate values occurring seaward of the shelf edge. It is assumed that once a short-lived bloom finds itself outside the system boundary it will die or be consumed by secondary producers. In either case it will sink (either as dead material or faecal pellets) and enter the "twighlight zone" where it is assumed to be exported (and sequestrated) carbon. Note that the remaining fraction of potential new production due to nitrate that sinks over the shelf is divided between " $F$ " (incorporated in shelf sediments) and "B" (the shelf re-cycling nitrate loop). It is suggested that a proportion of " $\mathrm{F}$ " may be transported off-shelf and sequestrated in continental slope sediments. This is analogous to the bottom nepheloid layer described by Swart and is shown as a dashed arrow in figure 1. The algebraic relationship between the network of nitrate pathways balances the various sources and sinks.

Satellite images of SST during upwelling events made it possible to quantify the amount of euphotic zone nitrate present seaward of the shelf edge (via the relationship between SST and integrated nitrate). It was found that on an event-scale, a maximum of $12.5 \%$ of the potential new production was occurring outside the system boundary. A mean of $3.6 \%$ was applied at the annual-scale (from an admittedly wide range of $0 \%-12.5 \%$ ). This pathway is de-coupled from the other pathways in the system and when substituting " $D$ " in the calculation of the range of " $E$ ", and hence " $F$ ", a conservative approach has been adopted.

“D” $=0.2(0.0-0.7) \times 10^{13} \mathrm{gCyear}^{-1}$

These three estimates can be substituted in Eqs. (1), (2) and (3) to give calculated estimates of the remaining three variables:

$$
\begin{aligned}
& \text { “A” }=3.9(2.7-5.1) \times 10^{13} \text { gCyear }^{-1} \\
& \text { "E" }=5.4(3.2-7.3) \times 10^{13} \text { gCyear }^{-1} \\
& \text { "F" }=3.7(1.0 \text { to } 6.1) \times 10^{13} \text { gCyear }^{-1}
\end{aligned}
$$

In summary, the above estimates suggest that the southern Benguela has the potential to export (and sequestrate)

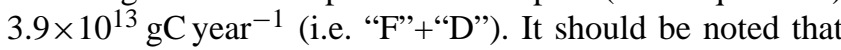
"F" may not be sequestrated in shelf sediments in its entirety. It is suggested that a proportion of " $F$ " may be transported off-shelf and sequestrated in continental slope sediments (Fig. 1).

\subsection{Monteiro: discrete upwelling centres - Gate Hypothesis Model}

The Gate Hypothesis, proposed that ocean - shelf exchange of thermocline waters occurred preferentially at a few specific sites characterized by shelf narrowing and maxima in the wind stress curl (Monteiro and van der Plas, 2006). These preferential exchange sites dominated by zonal flow (Cape Frio, Luderitz and Cape Columbine) act as barriers (Gates) to meridional flow thus creating shelf sectors with unique physical and biogeochemical properties (Monteiro, 2009). This has been shown to affect the variability of physical properties such as salinity and biogeochemical characteristics such as $\mathrm{CO}_{2}$ and hypoxia (Duncombe Rae, 2005; Monteiro, 2009). The basis for this has been strengthened by a recent calculation of the spatial characteristics of the regional wind stress curl that showed enhanced magnitudes at the Cape Frio, Lüderitz and Cape Columbine upwelling centres (Monteiro et al., 2005; Lass and Mohrholz, 2008). There is a subtlety regarding the inflow of $\mathrm{SACW}$ that precludes its inflow at Cape Columbine appearing overtly in Fig. 2. The SACW that enters the shelf in the vicinity of Cape Columbine through the Oliphants River Canyon (Dingle and Nelson, 1993) has identical characteristics to that which is advected across the ocean-shelf boundary at Lüderitz. For this reason the model was simplified to have fewer boundaries and the ocean-shelf exchange at Cape Columbine was removed. Each sector has an inflow of fresh SACW and an outflow of shelf-modified SACW. Each inflow acts as a "gate", limiting the further poleward advection of SACW from the northerly sector. Water does not outcrop at each upwelling centre directly from the slope, but as a 2 -step process. Once through the "gate", 


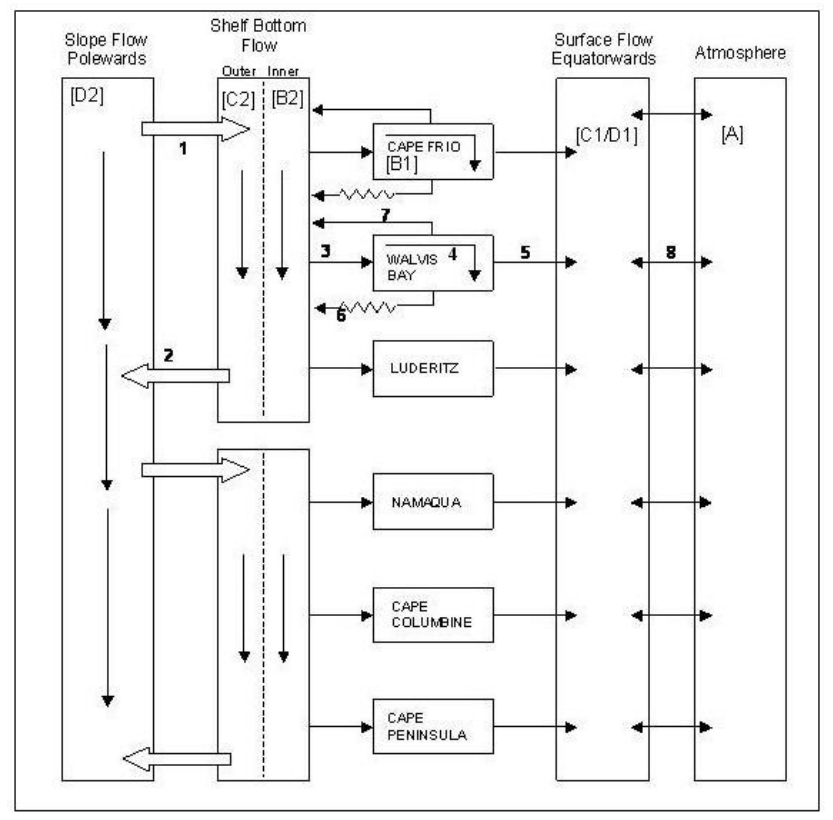

Fluxes:

1. $\mathrm{DIC}[\mathrm{D} 2-\mathrm{C} 2 / \mathrm{B} 2]$

2. DIC [C2/B2-D2]

3. $\mathrm{DIC}[\mathrm{B} 2-\mathrm{B} 1]$

4. $\mathrm{DIC}[\mathrm{B} 1-\mathrm{C} 1]$

5. DIC [C1-D1]

6. $\mathrm{DIC}[\mathrm{B} 1-\mathrm{B} 2]$

7. $\mathrm{DIC}[\mathrm{B} 1-\mathrm{B} 2 / \mathrm{C} 2]$

8. DIC $[\mathrm{A}-\mathrm{B} 1 / \mathrm{C} 1 / \mathrm{D} 1]$

Fig. 2. The conceptual model of the Benguela System: "Gate Hypothesis" of advective fluxes of dissolved inorganic carbon (later quantified with a box model).

SACW is entrained into a meridional shelf flow and the part which outcrops is the inner shelf water. In terms of carbon flux, this implies that the biogeochemical characteristics of upwelled waters are governed by the distance of the upwelling centre from the "Gate" rather than pre-formed characteristics of SACW and that carbon (POC and DOC) may be exported off the shelf to the slope at preferential sites.

This is schematically depicted by Monteiro (2009). The model adopted a published typology of upwelling centres that were summed to provide system and sub-system fluxes (Lutjeharms and Meeuwis, 1987). Upwelling in the model was forced by hourly wind-stress observations from each upwelling centre over two contrasting years: 1992 and 1994 (Monteiro, 1996). The model was a simple Ekman flux calculation forced by equatorward wind stress that persisted for periods longer than the inertial oscillation period (Monteiro, 1996). The whole Benguela system is shown in Fig. 2 and the model-derived southern system carbon fluxes are depicted in Fig. 3 using the Liu et al. (2000) typology. The biogeochemical fluxes were calculated based on the total annual Ekmanbased upwelling rates at each upwelling centre and the con-

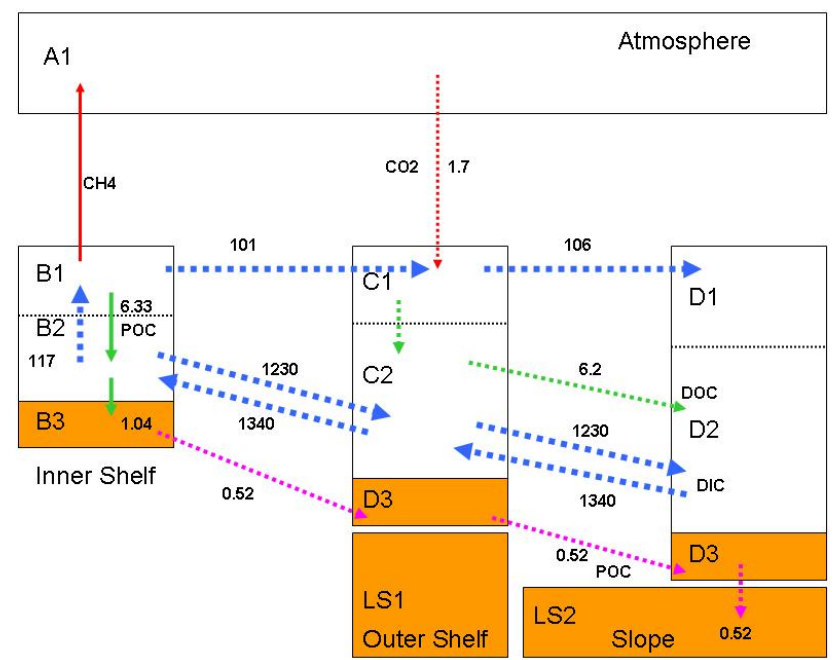

Southern Benguela Carbon Fluxes

Fig. 3. Southern Benguela carbon fluxes.

centrations of the biogeochemical constituents at each stage of the upwelling cycle (Monteiro, 1996, 2009). The whole system has six upwelling centres from Cape Frio in the north to Cape Point in the south. The northern sub-system comprises the Lüderitz, Walvis Bay and Cape Frio upwelling centres, whereas the southern sub-system, which is the focus of this study, comprises the Cape Peninsula, Cape Columbine and Namaqua upwelling centres (Fig. 2), which define the aggregated fluxes in Fig. 3.

The fluxes shown in Fig. 3 are million tons carbon per year $\left(=\mathrm{TgCy}^{-1}\right)$. The blue arrows represent dissolved inorganic carbon (DIC), the magenta arrows represent nepheloid fluxes of particulate organic carbon (POC) and the dotted green arrows represent fluxes of dissolved organic carbon. The results show that there is a substantial import of DIC but, by comparison, lesser exports of POC and DOC. The fluxes calculated from measurements and an Ekman model indicate that 1340 mTons DIC per year are transported from the outer to inner shelf (C2 to $\mathrm{B} 2$ ) but only 117 mTons per year are upwelled (B2 to B1). In order to compare equivalent fluxes between the Waldron and Monteiro approaches:

- Waldron's " $C$ " (southern Benguela annual potential production due to nitrate) of $5.6 \times 10^{13} \mathrm{gC}$ per year is equivalent to Monteiro's (B1 to $\mathrm{B} 2)+(\mathrm{C} 1$ to $\mathrm{C} 2$ to $\mathrm{D} 2)=(6.33+6.2) \times 10^{12}=1.35 \times 10^{13} \mathrm{gC}$ per year.

- Waldron's export (and sequestration) estimate of "F"+"D" $\left(3.9 \times 10^{13} \mathrm{gC} \mathrm{year}^{-1}\right)$ is equivalent to Monteiro's $(\mathrm{B} 2$ to $\mathrm{B} 3)+(\mathrm{C} 2$ to $\mathrm{D} 2)=(1.04+6.2) \times 10^{12}=$ $0.72 \times 10^{13} \mathrm{gC}$ per year. 


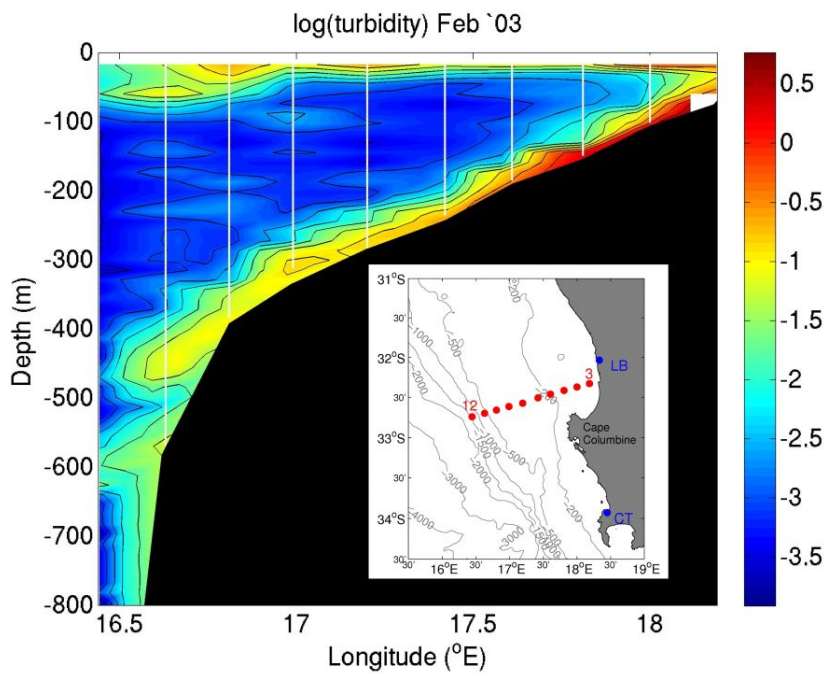

Fig. 4. Turbidity section from the southern Benguela (coastline to $16.5^{\circ} \mathrm{E}$ in the vicinity of St. Helena bay), illustrating the presence of a bottom nepheloid layer. Note that units for turbidity are a relative measure.

\subsection{Swart: cross-shelf advection in bottom nelpheloid layers}

Swart's study undertook to identify where in the water column shelf-ocean carbon exchange might occur, and to quantify the magnitude of such exchanges in the southern Benguela.

The methodology combined measurements of, inter alia, POC, turbidity and dissolved organic carbon (DOC) at 12 discrete stations spaced across the shelf and slope. A five year monthly time-series of turbidity revealed bottom nepheloid layers (BNLs) to be the preferential sites of particulate matter accumulation and perennial features of the southern Benguela shelf. Measurements on three separate occasions showed these bottom nepheloid layers to also be enriched in organic carbon relative to the surrounding waters (Fig. 4). Statistically significant regressions and correlations between POC and turbidity were established in these bottom waters and it was thus possible to use routinely measured turbidity as a proxy for seldom measured POC. There was a difference between summer and winter relationships. The summer relationship (March) was $y=82 x+42.7\left(r^{2}=0.16, p=\right.$ $0.03)$ and the winter, an average obtained from two cruises (June: $y=3.3 x+5.5, \mathrm{r}^{2}=0.73, p=<0.01$; and August: $\left.y=5.8 x+21.4, r^{2}=0.33, p=<0.01\right)$ where $x=$ turbidity and $y=\mathrm{POC}\left(\mu \mathrm{g}\right.$ litre $\left.^{-1}\right)$. Note that units for turbidity were relative, being the light-scattering output from the sensor mounted on the CTD. Thus the longer time series of turbidity was used to address the lateral transport of POC in the bottom nepheloid layer. A space vs time Hoffmöeller plot of turbidity $5 \mathrm{~m}$ off the bottom (Fig. 5) suggests that cross-shelf propagation of particulate material occurred in

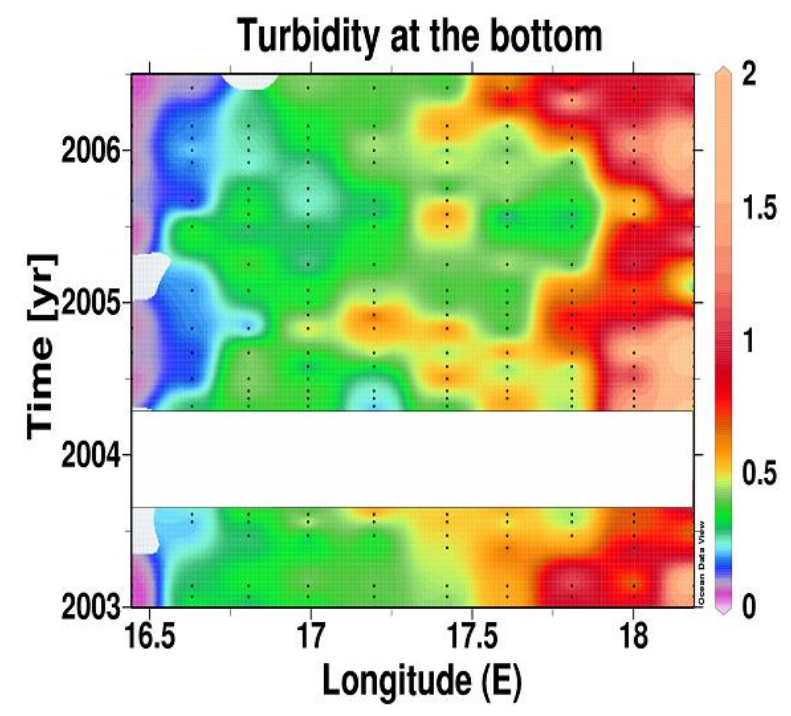

Fig. 5. Hoffmöeller plot of turbidity $5 \mathrm{~m}$ off the bottom. Tongues of high turbidity stretching across the shelf in time suggest a cross-shelf propagation of particulate matter The Shelf Break is at $16.75^{\circ} \mathrm{E}$. Note that the colour bar is not linear and that units for turbidity are a relative measure.

time (seasonal changes in particulate matter supply or bottom turbulence regimes cannot explain the pattern). A simple analytical model, based on the observed cross-shelf decay rate of organic material, estimated the annual off-shelf flux of POC in the BNL as $5.9 \times 10^{10} \mathrm{gC} \mathrm{yr}^{-1}$ (see Swart, 2008 for details). The measured shelf-ocean DOC gradient was used to crudely estimate the potential DOC export in the $\mathrm{BNL}$ as $8 \times 10^{11} \mathrm{gC} \mathrm{yr}^{-1}$. Along-isopycnal export of DOC throughout the water column was recognized as a potentially important process, but was not assessed. The main conclusions from Swart's study were that BNLs are regions of preferential organic matter accumulation and decay in the water column; DOC concentrations are often orders of magnitude greater than POC concentrations, with correspondingly greater BNL export rates, and the lateral carbon export in the BNL achieves about $25 \%$ of that required to make the southern Benguela system carbon neutral with respect to the atmosphere.

\section{Discussion}

\subsection{The magnitude of the boundary fluxes in the south- ern Benguela}

The carbon export results for the southern Benguela upwelling system from the approaches given above can be summarized as follows:

- Waldron: $3.9 \times 10^{13} \mathrm{gC} \mathrm{year}^{-1}$.

- Monteiro: $0.72 \times 10^{13} \mathrm{gC} \mathrm{year}^{-1}$. 
- Swart: $8.6 \times 10^{11} \mathrm{gC} \mathrm{year}^{-1}$; alternatively $0.86 \times 10^{12}$ $\mathrm{gC}$ year $^{-1}$.

An independent assessment of the Waldron and Monteiro estimates conducted by Prof. G. B. Brundrit, University of Cape Town (personal communication, 1997) stated: "Two models are presented. The first [Waldron] is solely twodimensional, being integrated longshore. The second [Monteiro] breaks the Benguela system into a series of upwelling centres, treating them separately and adding the results together for a system flux. The two models are complementary in that the first provides an upper bound and the second provides a lower bound for the fluxes". After conducting calculations based on water fluxes it was further stated: "Given the different approaches taken, the values are remarkably similar. Waldron's value could be expected to be on the high side given the uniform extrapolation along the coast. Monteiro's value could be expected to be on the low side given the omission of upwelling between the centres. It is therefore reasonable to use them as upper and lower bounds respectively for the southern Benguela upwelling, and then to compare with the results from [the] other regions".

At this stage it is a worthwhile exercise to examine (in the context of other studies) the estimate of southern Benguela annual potential production due to nitrate $\left(5.6 \times 10^{13} \mathrm{gC} \mathrm{year}^{-1}\right)$ provided by Waldron.

- Extrapolating daily ${ }^{15} \mathrm{~N}$ uptake measurements from a series of research cruises in new, mature and aged upwelling waters of the southern Benguela to the regional scale gave a mean annual new production rate of $1.4 \times 10^{13}$ gC year $^{-1}$ (Waldron et al., 1997).

- Total primary production for the southern Benguela has been estimated as $7.64 \times 10^{13} \mathrm{gC} \mathrm{year}^{-1}$ (Brown et al., 1991). The Waldron estimate of annual potential new production from this study implies an " $\mathrm{f}$ "-ratio of 0.73 .

- The daily rate for total primary production obtained from ${ }^{14} \mathrm{C}$ uptake studies in the Cape Columbine/St. Helena Bay region of the southern Benguela (Shannon and Field, 1985) was approximately $4.0 \mathrm{gC} \mathrm{m}^{-2} \mathrm{~d}^{-1}$. Expressing the results of this study in the same units gave a rate of $2.87 \mathrm{gC} \mathrm{m}^{-2} \mathrm{~d}^{-1}$ implying an "f"-ratio of 0.72 .

These comparisons and the associated f-ratios confirm that $5.6 \times 10^{13} \mathrm{gC} \mathrm{year}^{-1}$ is an estimate of potential production due to a parameterised upwelled nitrate flux rather than production due to nitrate uptake per se. It is important to note that potential production assumes the complete assimilation of all available nitrate. All the nitrate is unlikely to be used at the event scale, however, over longer time (and wider space) scales it is likely to be utilized, unless there is a means of transporting the nitrate below the euphotic zone. Also note that the Waldron estimate of annual potential production due to nitrate ("C" $=5.6(3.9-7.3) \times 10^{13} \mathrm{gC} \mathrm{year}^{-1}$ ) is likely to be an overestimate for reasons inherent in the methodology. In the southern Benguela, upwelling is seasonal, occurring mainly in the Spring and Summer months (nominally, September to January inclusive). Upwelling favourable winds do blow during other periods but with less frequency and intensity. The upwelling index did not exclude the Winter months and an adjustment to take this into account leads to a revised estimate of $4.2(2.9-5.5) \times 10^{13} \mathrm{gC}$ year $^{-1}$. The magnitude of the f-ratio based on direct observations of ${ }^{15} \mathrm{~N}$ uptake rates was found to be in the range of $0.2-$ 0.3 (Probyn, 1992). This magnitude is $30-50 \%$ of the calculated f-ratio from potential new production so the estimate of PNP can be further revised downwards to 0.5$2 \times 10^{13} \mathrm{gC}$ year ${ }^{-1}$ which is now very close to the box model estimate of $0.72 \times 10^{13} \mathrm{gC}_{\text {year }}{ }^{-1}$.

The magnitude of the flux estimated by Swart (2008) is around $2 \%$ of the figure given by Waldron, and around $10 \%$ that of Monteiro. It should be emphasized that the estimate of Swart pertains only to lateral carbon export in the bottom nepheloid layer, the preferential site of detrital accumulation in the southern Benguela. Thus Swart's figures are useful as an indication of the importance of the BNL, rather than an estimate of the total lateral carbon flux. Further, the monthly sampling of Swart was only able to resolve low frequency off-shelf advection of organic matter. High frequency pulses of organic matter export induced by turbidity currents or rapid, episodic downwelling events were not taken into account. Therefore $0.8 \times 10^{12} \mathrm{gC} \mathrm{year}^{-1}$ is likely an underestimate, and indicates that the true lateral export in the BNL could form a significant fraction of the total carbon export from the southern Benguela. Lateral export of POC by intermediate nepheloid layers sustained by sea bed turbulence (Monteiro et al., 2005), as observed by Inthorn et al. (2006), and along isopycnal export of DOC at surface and intermediate depths, could likely account for the remaining discrepancy in the figures of Swart and Waldron/Monteiro. This is an area of further investigation.

\subsection{The link between $\mathrm{CO}_{2}$ sink and ocean - shelf exchange of $\mathrm{POC}$ and DOC}

The importance of shelf - ocean POC and DOC carbon export fluxes lies is the role that they play in determining the magnitude of the net sink for atmospheric $\mathrm{CO}_{2}$ on the shelf system (Chen and Borges, 2009; Monteiro 2009). The southern Benguela upwelling system covers an area which is approximately $0.3 \%$ of the global shelf area and a comparable fraction of the global shelf $\mathrm{CO}_{2}$ uptake from the atmosphere (Chen and Borges, 2009).

The box model output shows the southern Benguela to be a sink of $\mathrm{CO}_{2}$ with an annual magnitude of $1.7 \mathrm{MtC}$ (Fig. 3), which is a small fraction of the global shelf $\mathrm{CO}_{2}$ sink of $360 \mathrm{MtCy}^{-1}$ (Chen and Borges, 2009). However, the area specific fluxes for the southern Benguela $\left(16.3 \mathrm{~g} \mathrm{Cm}^{-2}\right.$ year $\left.{ }^{-1}\right)$ are comparable in magnitude to other 
upwelling and shelf systems (Chen and Borges, 2009; Santana-Casiano et al., 2009). A sensitivity analysis undertaken with the Benguela box model showed that the magnitude of the $\mathrm{CO}_{2}$ sink is sensitive to both the POC export flux and fraction of the DOC flux that is oxidised prior to being transported by turbulent mixing or isopycnal mixing to sub-thermocline waters. The DOC flux was also the least constrained flux in the model derived as a mass balance closure term from the non-Redfield anomalies in the uptake of $\mathrm{CO}_{2}$ and $\mathrm{NO}_{3}$ (Monteiro, 1996). However, the most recent estimate of the magnitude of $\mathrm{CO}_{2}$ sink flux $\left(14.4 \mathrm{~g} \mathrm{Cm}^{-2}\right.$ year $\left.^{-1}\right)$ derived from direct observations of $p \mathrm{CO}_{2}$ over the seasonal cycle of 2 years (20052006) (Santana-Casiano et al., 2009) is in close agreement with the comparable magnitude from the box model $\left(16.3 \mathrm{gCm}^{-2}\right.$ year $\left.^{-1}\right)$. The agreement of the two independent estimates provides some confidence in the overall magnitudes of the POC export fluxes and particularly the DOC export, derived by the box model.

Although the DOC concentration observations were obtained more recently by in situ observation (Swart, 2008), the calculated flux was based on a horizontal diffusion assumption which is likely to significantly underestimate the actual cross shelf export flux. This makes it difficult to compare the model and observation based cross shelf export fluxes of DOC which differ by an order of magnitude (model: $6 \times 10^{12} \mathrm{gC}$ year $^{-1}$; direct observation $0.8 \times 10^{12} \mathrm{gC}_{\text {year }}{ }^{-1}$ ). Given the model's $\mathrm{CO}_{2}$ sink sensitivity to the magnitude of the DOC flux and its oxidation, it is likely that the data based calculation of the DOC export flux is too low and emphasises that the link between $\mathrm{CO}_{2}$ sink and POC and DOC export across the ocean shelf boundary remains an important area of investigation.

This investigation into the links between the magnitude of $\mathrm{CO}_{2}$ sink in shelf systems and the proportion of the production which is exported across the ocean-shelf boundary highlights the gaps in the observational and modelling scales necessary to adequately understand the dynamics of these links. Of particular interest are the spatial and temporal scales of the physical processes (internal tide driven turbulence, Ekman and non-Ekman advection, sedimentation) that govern rates and magnitudes of ocean - shelf exchange on the one hand and the biogeochemical rates of oxidation of both POC and DOC. A $\mathrm{CO}_{2}$ sink in any upwelling system reflects a net autotrophic status of the system integrated over seasonal time scales and the sink will remain sensitive to forcing factors which alter the rate of oxidation and the rates of transport and export across the shelf boundary.

Edited by: P. Chapman

\section{References}

Biscaye, P. E., Flagg, C. N., and Falkowski, P. G.: The Shelf Edge Exchange Processes experiment, SEEP-II an introduction to hypotheses, results and conclusions, Deep-Sea Res. II, 41(2/3), 231-252, 1994.

Brown, P. C., Painting, S. J., and Cochrane, K. L.: Estimates of phytoplankton and bacterial biomass and production in the northern and southern Benguela ecosystems, S. Afr. J. Marine Sci., 11, 537-564, 1991.

Chavez, F. P. and Toggweiler, J. R.: Physical Estimates of Global New Production: The Upwelling Contribution, Environ. Sci. Res. Reps., 18, 313-320, 1995.

Chen, C., Liu, K., and Macdonald, J. R.: Ocean biogeochemistry: a synthesis of the Joint Global Ocean Flux Study (JGOFS), Springer-Verlag, New York, Ch. 3, 53-95, 2003.

Chen, C.-T. A. and Borges, A. V.: Reconciling opposing views on carbon cycling in the coastal ocean: Continental shelves as sinks and near-shore ecosystems as sources of atmospheric $\mathrm{CO}_{2}$, Deep-Sea Res. II, 56(8-10), 578-590, 2009.

Dingle, R. V. and Nelson, G.: Sea-bottom temperature, salinity and dissolved oxygen on the continental margin off south-western Africa, S. Afr. J. Marine Sci., 13, 33-49, 1993.

Doney, S. C., Tilbrook, B., Roy, S., Metzl, N., Le Quéré, C., Hood, M., Feely, R. A., and Bakker, D.: Surface-ocean $\mathrm{CO}_{2}$ variability and vulnerability, Deep-Sea Res. II, 56(8-10), 578-590, 2009.

Duncombe Rae, C. M.: A demonstration of the hydrographic partition of the Benguela upwelling ecosystem at $26^{\circ} 40^{\prime} \mathrm{S}$, Afr. J. Marine Sci., 27(3), 617-628, 2005.

Falkowski, P., Laws, E., Barber, R., and Murray J.: Ocean biogeochemistry: a synthesis of the Joint Global Ocean Flux Study (JGOFS), Springer-Verlag, New York, Ch. 4, 99-121, 2003.

Hopkinson Jr., C. S., Vallino, J., and Nolin, A.: Decomposition of dissolved organic matter from the continental margin, Deep-Sea Res. II, 49, 4461-4478, 2002.

Ianson, D., Feely, R. A., Sabine, L., and Juranek, L. W.: Features of coastal upwelling regions that determine net air-sea $\mathrm{CO}_{2}$ flux, J. Oceanogr., 65, 677-687, 2009.

Inthorn, M., Wagner, T., Scheeder, G., and Zabel, M.: Lateral transport controls distribution, quality, and burial of organic matter along continental slopes in high-productivity areas, Geology, 34(3), 205-208, 2006.

Lass, H. U. and Mohrholz, V.: On the interaction between the subtropical gyre and the Subtropical Cell on the shelf of the SE Atlantic, J. Marine Syst., 76, 1-43, 2008.

Liu, K. K., Iseki, K., and Chao, S. Y.: Continental margin carbon fluxes, in: The changing ocean carbon cycle, edited by: Hanson, R. B., Ducklow, H. W., and Field, J. G., Cambridge University press, 187-239, 2000.

Lutjeharms, J. R. E. and Meeuwis, J. M.: The extent and variability of South-East Atlantic upwelling, in: The Benguela and Comparable Ecosystems, edited by: Payne, A. I. L., Gulland, J. A., and Brink, K. H., S. Afr. J. Marine Sci., 5, 51-62, 1987.

Malone, T. C., Hopkins, T. S., Falkowski, P. G., and Whitledge, T. E.: Production and transport of phytoplankton biomass over the continental shelf of the New York Bight, Cont. Shelf Res., 1, 305-337, 1983.

Monteiro, P. M. S.: The oceanography, the biogeochemistry and the fluxes of carbon dioxide in the Benguela upwelling system, $\mathrm{Ph} \mathrm{D}$ thesis, University of Cape Town, South Africa, 354 pp., 1996. 
Monteiro, P. M. S., Nelson, G., van der Plas, A., Mabille, E., Bailey, G. W., and Klingelhoeffer, E.: Internal tide-shelf topography interactions as a potential forcing factor governing the large scale sedimentation and burial fluxes of particulate organic matter (POM) in the Benguela upwelling system, Cont. Shelf Res., 25, 1864-1876, 2005.

Monteiro, P. M. S. and van der Plas, A. K.: Forecasting Low Oxygen Water (LOW) variability in the Benguela System, in: Benguela: Predicting a Large Marine Ecosystem, edited by: Shannon, V., Hempel, G., Malanotte-Rizzoli, P., Moloney, C., and Woods, J., Elsevier Series, Large Marine Ecosystems Part II, Chapter 5, 2006.

Monteiro, P. M. S.: Carbon fluxes in the Benguela Upwelling System, in: Carbon and Nutrient Fluxes in Continental Margins: A Global Synthesis, edited by: Liu, K. K., Atkinson, L., Quiòones, R., and Talaue-McManus, L., Springer, Berlin, in press, 2009.

Probyn, T. A.: The inorganic nitrogen nutrition of phytoplankton in the southern Benguela: new production, phytoplankton size and implications for pelagic foodwebs, S. Afr. J. Mar. Sci., 12, 411-420, 1992.

Roemmich, D.: Mean transport of mass, heat, salt and nutrients in southern California coastal waters: implications for primary production and nutrient cycling, Deep-Sea Res., 36, 1359-1378, 1989.

Rowe, G., Smith, S., Falkowski, P., Whitledge, T., Theroux, R., Phoel, W., and Ducklow, H.: Do continental shelves export organic matter?, Nature, 324, 559-561, 1986.
Rullkötter, J.: Organic matter: The driving force for early diagenesis, in: Marine Geochemistry, edited by: Schulz, H. D. and Zabel, M., Springer, Berlin, Ch. 4, 129-172, 2000.

Santana-Casiano, J. M., González-Dávila, M., and Ucha, I. R.: Carbon dioxide fluxes in the Benguela upwelling system during winter and spring: A comparison between 2005 and 2006, Deep-Sea Res. II, 56(8-10), 533-541, 2009.

Shannon, L. V. and Field, J. G.: Are fish stocks food-limited in the southern Benguela pelagic ecosystem?, Mar. Ecol. Prog. Ser., 22(1), 7-19, 1985.

Swart, N. C.: Lateral carbon transport from the southern Benguela. MSc. Thesis, University of Cape Town, South Africa, 139 pp., 2008.

Waldron, H. N., Probyn, T. A., and Brundrit, G. B.: Preliminary annual estimates of regional nitrate supply in the southern Benguela using coastal sea level fluctuations as a proxy for upwelling, S Afr. J. Marine Sci., 18, 93-105, 1997.

Waldron, H. N., Probyn, T. A., and Brundrit, G. B.: Carbon Pathways and export associated with the southern Benguela upwelling system: a re-appraisal, S. Afr. J. Marine Sci., 19, 113118,1998

Walsh, J. J., Rowe, G. T., Iverson, R. L., and McRoy, C. P.: Biological export of shelf carbon is a sink of the global $\mathrm{CO}_{2}$ cycle, Nature, 291, 196-201, 1981.

Wollast, R.: The Global Coastal Ocean: Processes and Methods. The Sea, Vol. 10, John Wiley \& Sons, New York, Ch. 9, 213 252, 1998. 